\title{
STRATIGRAPHY, STRUCTURE AND IGNEOUS FEATURES OF THE ANGNERTUSSOQ LAYER OF THE FISKENÆSSET COMPLEX
}

\author{
Brian F. Windley
}

\section{Introduction}

A prominent layer of the Fiskenæsset complex (Kalsbeek \& Myers, 1973) extends for at least $10 \mathrm{~km}$ eastwards from Angnertussoq mountain which is situated about $14 \mathrm{~km}$ south-east of Fiskenæsset. Its stratigraphy is broadly similar to that of the Qeqertarssuatsiaq layer to the north (Windley, Herd \& Bowden, 1973), and to those parts of the Fiskenæsset complex in the Majorqap qâva area (Myers, 1973) and in the region north of Bjørnesund (Walton, 1973). Igneous textures and grading are extremely well preserved in the Angnertussoq layer, the grading providing a confirmation of the way-up of the stratigraphic succession indicated by the whole-rock chemistry (Windley et al., 1973).

Five weeks were spent mapping the stratigraphy and structure of the Angnertussoq layer on approximately 1:20 000 aerial photographs. At its narrowest it is less than $1 \mathrm{~m}$ thick and at its widest, $2 \mathrm{~km}$. It is bordered conformably by biotite/hornblende-bearing granitic gneisses. The complex in this area was recrystallised by at least an amphibolitegrade metamorphism and deformed by thrusting and two major phases of folding.

\section{Stratigraphy}

The main stratigraphic zones of the complex in this region are as follows:

Top

(Biotite-hornblende gneiss)

Amphibolite

Marble $(1.3 \mathrm{~m})$ and sapphirine-bearing rocks $(6 \mathrm{~m})$

Meta-anorthosite

Meta-chromitite $(20 \mathrm{~m}$ ) in $100 \mathrm{~m}$ wide zone of anorthosite

Meta-anorthosite

Meta-leucogabbro (homogeneous)

Meta-gabbro

Meta-leucogabbro (layered)

Meta-ultrabasics

Amphibolite

(Biotite-hornblende gneiss)
Approximate maximum thickness in metres 
With the exception of the gneisses all the above units are, in places, thinned out completely. The upper amphibolite is a prominent marker, but the lower is thin and for the most part absent in this region. The sapphirine-bearing rocks occur at 11 localities, marked $\mathrm{S}$ on Plate 2, and they occupy a consistent stratigraphic position at the top of the layered succession. The marble is present in five localities, marked $\mathrm{M}$ on Plate 2 , and tends to be closely associated with the sapphirine rocks. There is a prominent development of ruby corundum and kornerupine in several of the sapphirine localities. Garnet is not a common constituent of the uppermost anorthosites as it is in the Qeqertarssuatsiaq layer (Windley et al., 1973). There is little to add of stratigraphic significance to the other main zones of the complex except to emphasise that the ultramafics locally reach $110 \mathrm{~m}$ in thickness; as the ultramafic zone has so often been thinned and removed by deformation, this is a useful indication of an original minimum thickness.

On the south-west side of the Angnertussoq layer most zones have been 'replaced' by a pegmatite about $400 \mathrm{~m}$ wide and $3.5 \mathrm{~km}$ long. Inclusions of chromitite and gabbro occur within it in their correct stratigraphic position.

\section{Igneous features}

The ultramafic-anorthosite part of the succession has three types of igneous structure: cumulate textures, grading, and rhythmic layering.

Cumulate textures marked by plagioclase megacrysts occur in:

(a) The homogeneous leucogabbros. Many megacrysts are only partially recrystallised around their margins and in this central zone of the complex the rocks are often undeformed.

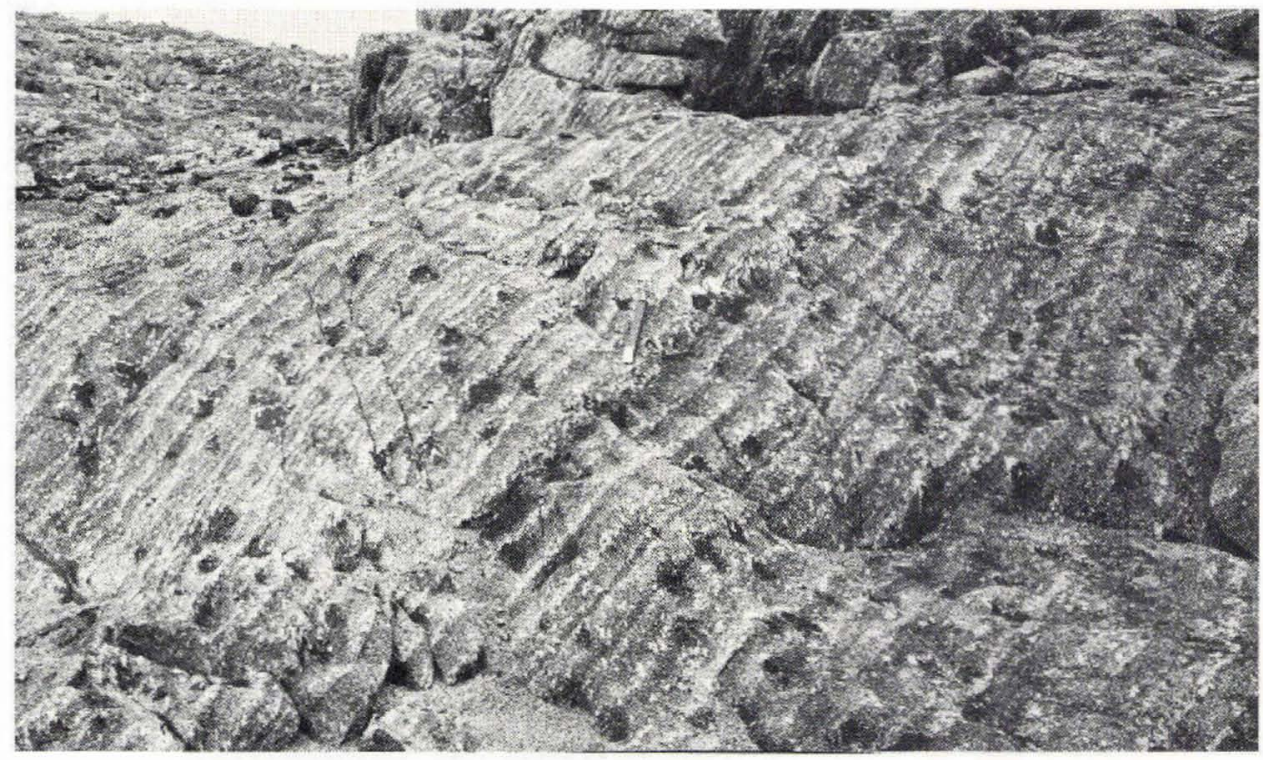

Fig. 26. Part of the graded-layered sequence in the eastern part of the Angnertussoq layer. About 40 graded layers are seen facing upwards to the right. The tops of the $10-20 \mathrm{~cm}$ wide layers are marked by white plagioclases. Black ultramafic cumulate pods are scattered throughout the sequence and generally decrease in size upwards to the right. 


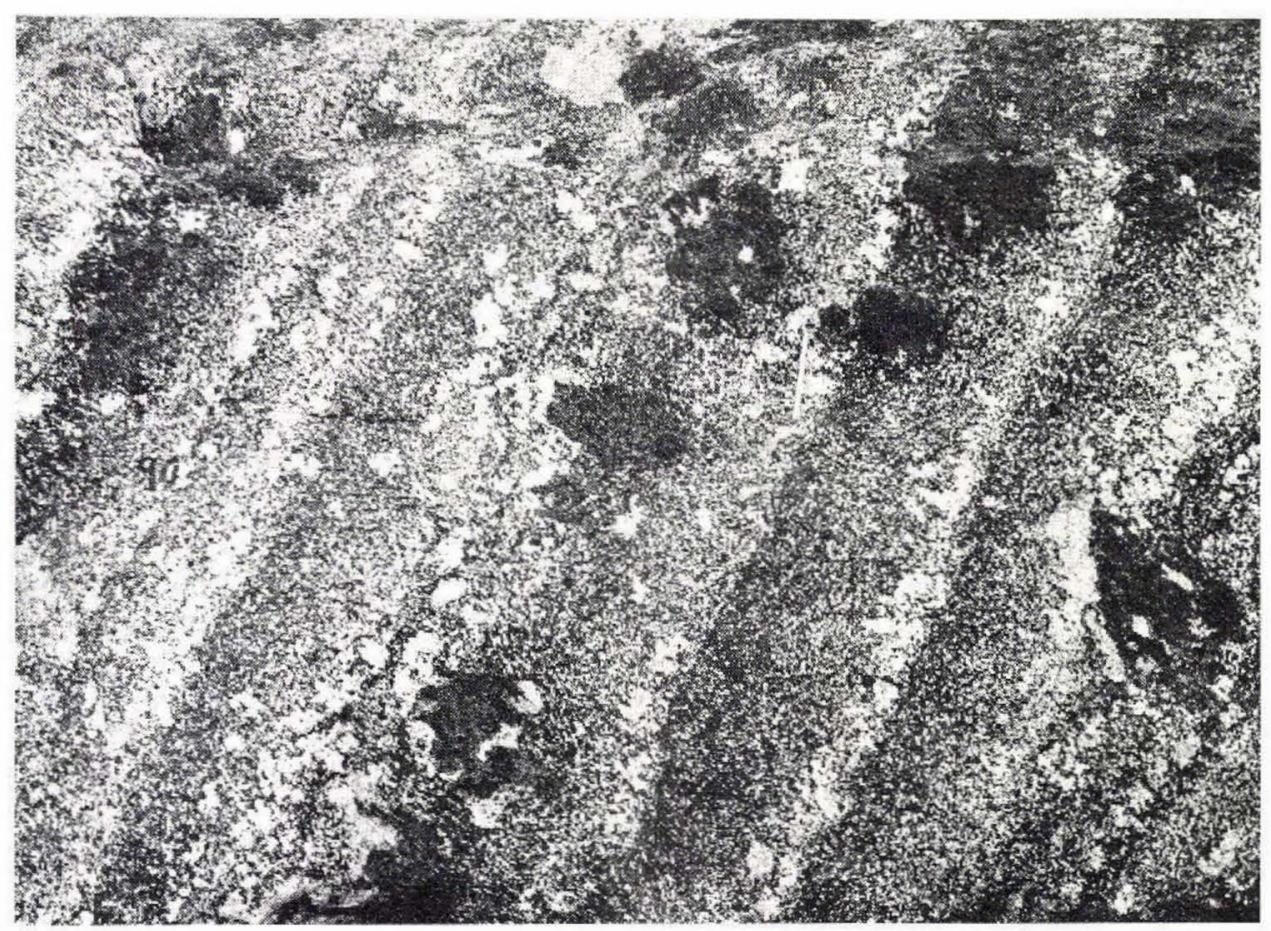

Fig. 27. Close-up of the graded-layered sequence showing the sharp mafic base and plagioclase-rich top of the layers which face to the right. Ultramafic cumulate pods in places have a white plagioclaserich rim around their base having sunk in the magma through the plagioclase-rich 'tops'.

(b) The layered leucogabbros. The megacrysts are much finer grained than in the homogeneous leucogabbros and the cumulate texture is commonly masked by a tectonic preferred mineral fabric parallel to the zone boundaries.

(c) The chromitites. In several low deformation areas the plagioclase megacrysts are unsheared, but typically they are deformed as ellipsoidal augen.

Grading and rhythmic layering occur in three zones:

(a) The chromitite layers are often made up of rhythmically alternating laminae of plagioclase and chromite-hornblende plagioclase. In one $8 \mathrm{~m}$ thick chromitite the plagioclase megacrysts are size graded.

(b) The lowermost ultramafics. The thickest $110 \mathrm{~m}$ thick succession consists of at least 30 layers, mostly composed of alternating orthopyroxene and hornblende. In some layers the orthopyroxenes have a reversed size grading, i.e. the tops of the layers are marked by the coarsest grains.

(c) The gabbro. There is a spectacular graded rhythmically-layered sequence (figs. 26 and 27) in a low deformation area where the neutral zone of an $\mathrm{F}_{3}$ fold crosses the neutral zone of an earlier isocline. About 700 layers are arranged in six cyclic units, each of which passes from a basal ultramafic (c. $30 \mathrm{~cm}$ wide), through a layered graded sequence 
$(10-13 \mathrm{~m})$ with between 100 and 150 layers (up to $20 \mathrm{~cm}$ wide), to gabbro (3-5 m) and anorthosite $(1 \mathrm{~m})$ at the top. (Unpublished electron micro-probe analyses at Chicago with J. V. Smith show that, where least deformed, these anorthosites consist largely of $\mathrm{An}_{\text {99-100 }}$ plagioclase.) Each layered graded sequence contains ultramafic cumulate pods (c. $10 \mathrm{~cm}$ diameter) that are themselves size graded (fig. 27). In the lowest deformation area the pods have axial ratios of about 1:1:1, and in the high deformation area associated with the cleavage of the major $\mathrm{F}_{3}$ fold the pods have ellipsoidal shapes with axial ratios of about 1:30:50 that lie well in the flattening field of the $X Y: Y Z$ deformation plot. This layered sequence occurs at the top of the gabbro zone and flattened equivalents of it can be found at five other localities at this stratigraphic position.

In the Angnertussoq layer grading was found at at least 40 localities, mostly within the gabbro zone. All examples gave the correct way-up of the stratigraphy confirming that this layer of the Fiskenæsset complex has an anticlinal structure.

\section{Structure}

The stratigraphy of the Angnertussoq layer shows that it has an anticlinal $\left(F_{1}\right)$ structure. In the south-east of the area there is a major $F_{3}$ fold core with an axial trace trending north-west. The north-east trending $F_{2}$ isoclines, common in other parts of the Fiskenæsset region, are absent on a major scale in this area.

The $F_{1}$ isocline has had the effect of duplicating the stratigraphy of the complex in the central part of the Angnertussoq layer, but at either end the two 'halves' of the complex diverge to become individual layers, each with a single unrepeated stratigraphy - the essentials of this structure are shown in fig. 28. It is clear that the reason for the 'diver-

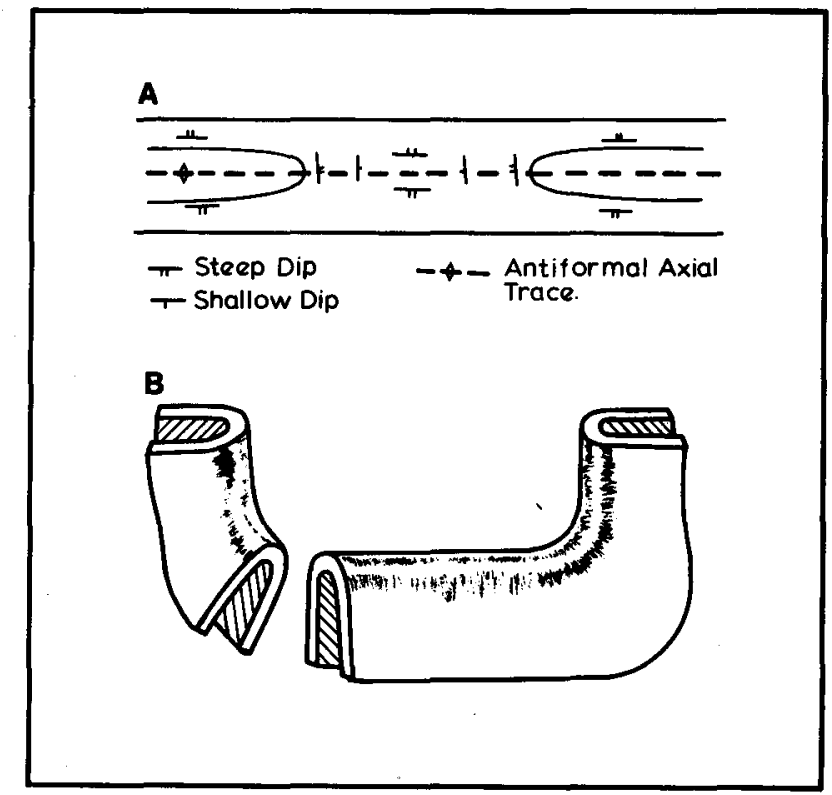

Fig. 28. A. Simplified illustration of the structure of the Angnertussoq layer of the Fiskenæsset complex without the effects of the $\mathrm{F}_{3}$ folding seen on plate 2 , and $\mathrm{B}$ as it would appear in three dimensions. 
gence' is the variation in plunge of the first fold axis relative to the ground surface; where it is flat-lying and where the hinge zone is close to the present topographic surface the isoclinal fold gives rise to a 'double' layer of the complex, with no gneiss between the two halves, but where the axis is folded into a steep or vertical position the two 'halves' are separated by the inner gneiss layer - an idealised picture of the structure is shown in fig. 28 .

There is considerable evidence of major thrusting:

(1) Repetition of the stratigraphy on one limb of the isocline. For example, the successive zones of the complex might be, in idealised terms: $1,2,3$, gneiss, 1, 2, 3, 4, 5, 6, 7. The intrusive gneiss layers are located along major thrusts. This gneiss is a distinctive homogeneous leucocratic type which looks very much like a deformed granite, similar to the typical Nûk gneisses in Godthåbsfjord (McGregor, 1973), and is unlike most of the other gneisses in the Angnertussoq area. The hinge zone of the $F_{1}$ isocline has been intruded by a similar granitic gneiss, seen as a $150 \mathrm{~m}$ wide layer on Plate 2 .

(2) A thin, but major, layer of the Fiskenæsset complex abuts discordantly against the south side of the Angnertussoq layer (inset A, Plate 2). The contact is marked by extreme shearing and mylonitisation of the thinner layer of the complex. This example shows that the contact between the upper amphibolite and the overlying gneiss is definitely a major thrust plane. The truncated narrower layer does not reappear anywhere else along the strike.

(3) In the core of the eastern $\mathrm{F}_{3}$ major fold the layering of the gabbro zone (marked by the graded-layered sequence indicated earlier) is truncated at right angles by the overlying homogeneous leucogabbro zone (inset B, Plate 1). Clearly much of the upper part of the gabbro zone, including the continuation of the graded-layered sequence, has been removed along this thrust plane. It seems that any of the contacts between the major zones of the complex may act as potential thrust planes, in particular those separating rocks with a high viscosity contrast.

(4) In several places there are up to $10 \mathrm{~m}$ thick belts of sheared or mylonitised rocks along major zone contacts. In the Qeqertarssuatsiaq layer there are $1 \mathrm{~m}$ wide garnetbearing mylonites indicative of the high temperature reached by some of these movement zones.

As the stratigraphy is so consistent throughout a large part of the Fiskenæsset complex, the absence of certain major zones in some areas may well be due, amongst other reasons, to removal by early thrusting.

\section{Acknowledgement}

I am grateful to G. Rivalenti for allowing me to map the easternmost part of the Angnertussoq layer in the border zone of his area. 


\section{References}

Kalsbeek, F. \& Myers, J. S. 1973: The geology of the Fiskenæsset region. Rapp. Grønlands geol. Unders. 51, 5-18.

McGregor, V. R. 1973: The early Precambrian gneisses of the Godthaab district, West Greenland. Phil. Trans. R. Soc. Lond. A 273, 343-358.

Myers, J. S. 1973: Igneous structures and textures in the Majorqap qâva outcrop of the Fiskenæsset anorthosite complex. Rapp. Grønlands geol. Unders. 51, 47-53.

Walton, B. J. 1973: The structure and stratigraphy of the anorthosite complex in the area north of Bjørnesund, near Fiskenæsset. Rapp. Grønlands geol. Unders. 51, 60-64.

Windley, B. F., Herd, R. K. \& Bowden, A. A. 1973: The Fiskenæsset complex, West Greenland. Part 1. A preliminary study of the stratigraphy, petrology and whole-rock chemistry from Qeqertarssuatsiaq. Bull. Grønlands geol. Unders. 106 (also Meddr Grønland 196,2) 80 pp. 